\title{
Does Ownership Structure Matter for Dividend Yield? Evidence from the Hong Kong Stock Exchange
}

\author{
Xuanfeng Zhang (Corresponding author) \\ University of British Columbia \\ 2357 Main Mall, Vancouver, Canada
}

Tel: 1-778-927-7790Ｅ-mail: xuanfeng.zhang@alumni.ubc.ca

Fu Jia

The Hong Kong Polytechnic University, Hung Hom, Kowloon, Hong Kong

Tel: 86-182-6813-2261Ｅ-mail: fujia_0119@163.com

Received: July 25, 2014 Accepted: August 6, 2014

doi:10.5296/ber.v4i2.6023 URL: http://dx.doi.org/10.5296/ber.v4i2.6023

\begin{abstract}
A research framework is developed to identify the key factors that would influence corporate dividend yield of Hong Kong listed companies. This study examines how ownership structure affects dividend yield using firm size, profitability, leverage, and firm development opportunities as control factors. The result reveals that ownership structure and profitability has the most important effect on divided yield. Firm size also determines the dividend payout but in negative relationship. It is suggested that firm leverage and market-to-book showed no significant influence on dividend policy. The findings in this study are useful for investors to understand what are the determinants of corporate dividend payout in Hong Kong so they can make wise and suitable choice.
\end{abstract}

Keywords: Corporate dividend yield, Firm size, Profitability, Leverage, Ownership structure, Firm development and opportunity 


\section{Introduction}

Consider the Board of Directors is holding a meeting to decide the dividend policy that is about to be declared to the public. The managers are facing with decision-making about whether they should pay dividends, or to retain them for re-investment and how much dividends yields they will pay. Financial Managers are very careful in handling the choice of dividend policies of a company as dividends not only influence the value of the firm but more importantly the wealth of their shareholders (Deepark, 2004). As the ultimate objective of all financial decisions is to maximize shareholders' wealth, the significant determinants of dividend policy are important inputs for the dividend decision-making process (Singhania \& Gupta, 2012). Dividend policy is also considered as an indicator for investors to make an informed decision while deciding on investments, and to predict the dividend yield in the future by analyzing significant determinants.

The scenario we depicted above is a common occurrence in the contemporary commerce environment. However, although many researchers have proposed theories and analyzed empirical evidence regarding the determinants of a firm's dividend policy, the issue remains under debate. Black (1976) in his study on dividends wrote, "The harder we look at the dividend picture the more it seems like a puzzle, with pieces that just don't fit together". More recently, Brealey and Myers (2005) listed dividends as one of the top 10 important unresolved problems in finance. It seems that dividend policy is one of the most debated topics in finance literature and still maintains its prominent position (Naceur, Goaied \& Belanes, 2006). More recently, Allen and Michaely (2003) concluded that before reaching a consensus, much more empirical and theoretical research on dividends is required. Therefore, the purpose of our research is to provide empirical findings that may help determine the best-fit model for the dividend "puzzle".

The legal policies vary between different counties, so the dividend policies may also substantially vary. For several reasons, the Hong Kong Stock Exchange (HKSE) serves as a useful foundation for our study. Firstly, a well-developed international stock market such as Hong Kong, as a typical and important representative could be surprises in terms of dividend policies adopted by Hong Kong companies. Secondly, Hong Kong has several advantages including strong legal system, sound regulatory framework, free flow of capital and information, international accounting standards, advanced clearing and settlement Infrastructure (Advantages of listing in Hong Kong, from http://www.hkex.com.hk/) ensuring the error terms to be minimized. Thirdly, as the number of both local and Mainland investors are growing in the Hong Kong financial market, more people demand public information from companies listed on HKSE (HKTDC, 2012). Finally, while several researchers have already made conclusions about the determinants of firms' dividend policies in emerging markets like India and other developed capital markets like the US, no specific study could be found regarding this issue in Hong Kong. Therefore, the aim of this study is to give a valid view about determinants of firms' dividend policies in the Hong Kong perspective.

While most of corporate finance literature focus on predicting abnormal returns (Jagannathan and Wang, 1996; Fung et al., 2014), the primary objective of the study is to understand and 


\section{Macrothink}

Business and Economic Research

ISSN 2162-4860

2014, Vol. 4, No. 2

analyze the determinants of dividend policy companies listed in HK using 120 firms in 2012, especially to test the impact of ownership structure on dividend yield.

The whole paper mainly consists of six sections. Section 1 gives overview of dividend policy. The section 2 is a review of literature, which refers to the leading determinants of dividend as proposed by various studies, including theoretical background. Then, Section 3 provides research framework and hypothesis statements. Section 4 describes research methodology including research design and data measurement. Section 5 presents the analytical results. Section 6 discusses limitations and future research direction. The last section summarizes the main findings and offers suggestions. 


\section{Literature Review}

Does dividend policy matter? Financial and business researchers have proposed several theories about dividend policy with the historical development of the corporation. A persuasive argument claimed that dividend policy does not matter. The one is closely related to the work of Modigliani and Miller and their irrelevant hypothesis (M\&M) (1961). M\&M demonstrated two propositions and in Proposition I, it stated that under certain assumptions including no corporate or personal tax or bankruptcy cost, the value of the firm is independent of its dividend policy. In other words, dividend policy is actually irrelevant and it does not impact the firm value.

However, most schools of thought contend that dividend policy does matter. The signaling hypothesis (information content of dividends) belongs to this kind of thought. The implication underlying this hypothesis is that usually inside managers have more private information about the health of the firm than outside investors and there is an information asymmetry between them. Outsiders believe that dividend changes convey information about the firm to the market and this fact makes it difficult to interpret the effect of firms' dividend policies. According to signaling equilibrium built by John and Williams (1985), corporate insiders with more valuable private information optimally distribute larger dividends and receive higher prices for them. In Bhattacharya's assumption (1979), outside investors have imperfect information about firms' profitability and that cash dividends are taxed at a higher rate than capital gains and under these conditions, such dividends function as a signal of expected cash flows. Generally an unexpected increase in the dividend signals a good new the reaction is that the stock price rises because expectations of future dividends are driven upward, and vice versa. Investors believe that only when firms' future earnings, cash flow, and general prospects are expected to improve to such an extent that the dividend are not necessarily to be cut, then management will raise the dividend. Support for the signaling hypothesis can be found in many researches, for example, in Waweru, Pokhariyal and Mwaura (2012), Balachandran, Mahamuni and Dempsey (2010), and Bali (2003). In contrast, other researchers found partial support or rejected the signaling hypothesis such as Li and Zhao (2008), Savov (2006), and Watts, (1973).

From signaling hypothesis, it is clear that an announcement of dividend increase is met with a positive stock price reaction, while the source of the gains is subject to debate. One explanation is that the dividends help reduce agency costs within the firm. The agency-cost hypothesis is another theory offered for solving the dividends "puzzle". According to Singhania and Gupta (2012), dividend payments can reduce the payments associated with information asymmetry and also reduce the cash flow under management control, thereby helping to remove agency problems. Borokhovich et al.(2005) found further evidence to prove dividends as a mechanism to reduce agency costs, that is, firms with a majority of strict outside directors on their boards experience significantly lower mean abnormal returns around the announcements of sizeable dividend increases. However, other researchers such as Norohna et al. (1996) presented evidence that the agency cost rationale is context specific and that dividends will not be driven by agency costs when other mechanisms exist for controlling agency problems. 


\section{Macrothink}

The third thought called the pecking order hypothesis, which was proposed by Myers and Majluf in 1984. The pecking order hypothesis predicates that the firms have tendency to rely on internal sources of funds, and to prefer debt to equity if external financing is required in order to reduce the costs of information asymmetry, transactions costs and other market imperfection. Two assumptions are assumed in this hypothesis. Management may aware more about the firm's value than outsider investors. Besides, these potential investors interpret the firm's actions rationally so that they believe firms with better growth will be more likely to retain funds for internal funding, re-investment and accordingly pay fewer dividends. Under this situation, firms may refuse to issue stock, and therefore may give up some valuable investment opportunities.

The last hypothesis states that stocks attract particular groups based on dividend yield and the resulting tax effect is called clientele effects hypothesis. It states that different groups of investors, such as wealthy individuals and corporations, desire different levels of dividends. For example, some groups (wealthy individuals) have an incentive to purse low-payout stocks and they will buy stock in those companies that offer low dividend payout because they are in upper income tax brackets, and vice versa. Investors tend to be attracted to the types of stocks that match their investing preferences. There are also numerous studies related to the clientele effect, but the results are mixed. In Marr and Trimble (1993) suggested that the clientele hypothesis appears to account for all but the largest abnormal returns and in Dale-Johnson's study (1983), the results tended to support the existence of the clientele effect in the residential real estate market. However, Abrutyn and Turner (1990) provided evidence about weak clientele dividend reactions.

As for tax-related theories, unlike the case in the United States, there are no taxes on dividend income or on capital gains in Hong Kong. According to Tax Regulation published in 2010, all profits arising in or deriving from Hong Kong are taxable, except (1) offshore income (2) dividend receipts and (3) capital gains.

Researches and theories discussed above illustrated different explanations for the determinant of corporate dividend policy and there is no consensus on which model can be the guide to investing decision, but all of them provide useful suggestions to solve the dividend "puzzle". 


\section{Research Framework}

The independent variables are firm size, profitability, leverage, ownership structure, and firm development. Our dependent variable is the dividend yield, which is affected by the independent variables. Although studies in our literature review described more factors affecting corporate dividend policy, we choose to focus on those items, which are accessible by the public through published annual reports and available data from Hong Kong Exchange and Clearing Limited. Our key variable of interest is corporate structure.

\section{Hypothesis 1: Larger firm size means higher dividend payout.}

Normally a larger size of a firm implies that it is in a more mature stage. These kind of large firms are more likely to pay dividends because it's easier for them to generate ample amounts of cash and they have faded good opportunities for their investment (Fama \& French, 2001). Although it has been normally considered that dividend payments have positive associations with firm size, the research conducted by Azeem, Akbar and Usman (2011) has proved that there is not any sort of positive association between dividend policy and firm size.

Here, market capitalization of common equity (MCAP), which is equal to number of shares outstanding multiply stock price, is used as a measure for size (Deshmukh, 2003) and a positive relationship is assumed.

\section{Hypothesis 2: Firm Profitability is positively associated with dividend payout}

Generally, researchers almost have common conclusions about the positive correlation between dividend payment and profitability. It should be noticed that different approaches were used to calculate or to define profitability, and each has its own limitations.

Naceur, Goaied and Belanes (2006) concluded that highly profitable firms with more stable earnings could afford larger free cash flows and thus pay out larger dividends. They solely use ROA, which is calculated by net income/total assets to measure profitability. $\mathrm{He}, \mathrm{Li}$ and Tang (2011) also wrote that firms with higher profitability imply that they have more free cash flows. Some companies pay dividends either for their own consumption or for building a good reputation through dividends payments and thus maintaining the competitiveness in financial markets. Their profitability are found a positive relation. On the contrary, some of the research showed the profitability attributed insignificant effects on the level of dividend paid. For example, Singhania and Gupta (2012) stated that the estimates of earnings per share (EPS) regarding the profitability are positive and, contrary to expectation, insignificant. Their assumption was based on Lintner's model published in 1956, that is dividend depends on earnings of the previous year and dividends of the year before.

Based on the above discussion, earnings per share (EPS) is used as a measure of a firm's profitability in this hypothesis and positive relationship is assumed.

\section{$>$ Hypothesis 3: Firm leverage is negatively associated with dividend payout}

There are several studies that demonstrated the negative relationship between firm debt and dividend payout. According to Asifetal (2010), dividend decreases actually increase the debts 
of a company. For firms, they need to maintain their internal cash flow to pay their fixed financial charges rather than distribute the cash to shareholders because failures to meet this obligation may lead the firm into risk. For those who have high financial leverage, they have a tendency to reduce the transaction costs by lowing payout ratios. More evidence is provided by Yan and Kam (2012), the results showed that there is a meaningful and negative relationship between financial leverage and payout. Other researchers, such as Myers and Frank (2004), examined the data for a sample of 483 firms from Multex Investor Database and surprisingly found that debt to equity ratio was positively related with dividend payout.

Here, the hypothesized relationship between financial leverage and dividend is negative and financial leverage is measure by the ratio of total debt and total equity of the firm (DER).

\section{> Hypothesis 4: Ownership Structures affect corporate dividend payout}

Ownership is an important determinant in the dividend decision-making process. It is complex to address the relationship between ownership structures and dividend policy because of the variety of owners of Hong Kong firms (for example, families, institutions, government, and foreign investors). According to the research of Kumar (2012) in India, the association between ownership structure and dividend payout policy differs across different group of owners and at different level of shareholding. Warrad, et al. (2012) provided empirical results which revealed that there is no relationship between private, government ownership structure and the dividends policy measured by Tobin's Q. Meanwhile, a positive and significant relation between foreign ownership and dividend payout policy are revealed. Furthermore, the results of Faris et al. (2012) indicated that there is a significantly negative relationship between the state ownership and the level of dividend distributed to shareholders. In another related study, Gugler (2003) examined 214 non-financial Australian firms from 1991 to 1999 and argued that state owned firms were engaged in dividend smoothing and they also concluded that the state owned firms were most reluctant and family owned firms were least reluctant to cut dividends. Thanatawee (2013) examined the relationship between ownership structure and dividend policy in Thailand and found if the largest shareholder is an institution they pay higher dividends than others. Eckbo and Verma (1994) suggested institutional shareholders prefer distribution of dividends in an attempt to reduce agency costs.

Four dummy variables were introduced in describing the ownership structure of the firm, which are family (FAML), state (STATE) and institution (INST) and we assume that dividend payouts are negatively related to FAML, but positively related with STATE and INST.

\section{Dypothesis 5: Growth opportunities affect corporate dividend payout}

According to the pecking order hypothesis proposed by Myers and Majluf (1984), those who have high growth and investment opportunities are likely to demand more internal funds to finance their future investments, and thus they are tend to pay few or no dividends. Besides, they have to adapt their target dividend payout to their investment opportunities, while trying to avoid sudden changes in dividends. Even if external financing is required, they start with debt, and view equity as a last resort. 
Myers (1977) contended that market-to-book ratio indicates growth opportunities, which can be thought of as real options. Here, we use Market Price to Book Value Ratio, which is a simple way of judging whether a company is under or overvalued, to measure the firm's growth opportunities and we assume it is negatively related to dividend payout (Deshmukh, 2003; Aivazian et al., 2003).

Table. 1. Summary of the hypotheses statements.

\begin{tabular}{|c|c|c|}
\hline Related Hypotheses & Theories \& Description & Proxy Variable(s) \\
\hline $\begin{array}{l}\text { Hypothesis 1: Firm Size } \\
\text { is positively associated } \\
\text { with dividend payout }\end{array}$ & $\begin{array}{l}\text { It's easier for large company to access to ample } \\
\text { capital and rely less on internal funds. Therefore, } \\
\text { they are likely to pay more dividends. }\end{array}$ & $\begin{array}{l}\text { MCAP, market capitalization } \\
\text { of common equity (Deshmukh, } \\
\text { 2003; Aivazian et al., 2003) }\end{array}$ \\
\hline $\begin{array}{l}\text { Hypothesis } 2 \text { : Firm } \\
\text { Profitability is positively } \\
\text { associated with dividend } \\
\text { payout }\end{array}$ & $\begin{array}{l}\text { Lintner's model (1956): Dividend depends on } \\
\text { firm's current earnings and dividends of previous } \\
\text { year. }\end{array}$ & $\begin{array}{l}\text { EPS, earnings per share } \\
\text { (Singhania and Gupta, 2012) }\end{array}$ \\
\hline $\begin{array}{l}\text { Hypothesis } 3 \text { : Firm } \\
\text { leverage is negatively } \\
\text { associated with dividend } \\
\text { payout }\end{array}$ & $\begin{array}{l}\text { Cash flow is required to meet obligations of } \\
\text { creditors and lenders firstly. (Asif et al, 2010; } \\
\text { Tin-yan and Shu-kam, 2012) } \\
\text { Firms have a tendency to reduce the transaction } \\
\text { costs associated with external financing by } \\
\text { making dividends lower. }\end{array}$ & DER, Debt to Equity Ratio \\
\hline $\begin{array}{l}\text { Hypothesis 4: Ownership } \\
\text { Structures affect } \\
\text { corporate dividend } \\
\text { payout } \\
\text { Dividend payouts are } \\
\text { negatively related to } \\
\text { FAML, but positively } \\
\text { related with STATE and } \\
\text { INST }\end{array}$ & $\begin{array}{l}\text { Agency theory in the case of HK is very } \\
\text { important to address. } \\
\text { The state owned firms were most reluctant and } \\
\text { family owned firms were least reluctant to cut } \\
\text { dividends. Gugler (2003). If the largest } \\
\text { shareholder is an institution they pay higher } \\
\text { dividends than others. Thanatawee (2013); } \\
\text { Eckbo and Verma (1994) }\end{array}$ & $\begin{array}{l}\text { Family (FAML), state } \\
\text { (STATE) and institution } \\
\text { (INST) }\end{array}$ \\
\hline $\begin{array}{l}\text { Hypothesis 5: Growth } \\
\text { opportunities negatively } \\
\text { affect corporate dividend } \\
\text { payout }\end{array}$ & $\begin{array}{l}\text { Pecking order hypothesis Myers and Majluf } \\
\text { (1984) : Those who have investment } \\
\text { opportunities are likely to demand more internal } \\
\text { funds to finance their future investments, and } \\
\text { thus they are tend to pay few or no dividends. }\end{array}$ & $\begin{array}{l}\text { MBR, market-to-book ratio. } \\
\text { (Myers, 1977) (Market price } \\
\text { prevalent in capital market / } \\
\text { the book value of the } \\
\text { company) }\end{array}$ \\
\hline
\end{tabular}




\section{MInstitute ${ }^{\text {Macrothink }}$}

\section{Procedures/Methodology}

\subsection{Research design}

The research model drawn below shows the relationship between independent variables and the dependent variable. We use multivariate regression to analyze which independent variables will significantly affect firms' dividend yield. Sample regression model is written as:

$$
\mathrm{DYLD}=\hat{\beta}_{0}+\hat{\beta}_{1} * \mathrm{EPS}+\hat{\beta}_{2} * \mathrm{MCAP}+\hat{\beta}_{3} * \mathrm{DER}+\hat{\beta}_{4} * \mathrm{FAML}+\hat{\beta}_{5} * \mathrm{STATE}+\hat{\beta}_{6} * \mathrm{INST}+\hat{\beta}_{7} * \mathrm{MBR}+\varepsilon \mathrm{i}
$$

DYLD representes the dividend yield, defined as dividend-to-price ratio. EPS is the after-tax earnings per share. MCAP is the natural $\log$ of market capitalization. DER denotes the debt-equity ratio. FAML, STATE and INST are dummies for family-owned, government-run and institutions. MBR is the market-to-book value ratio.

\subsection{Sampling and Data Collection}

The data of this research are all listing companies that pay dividends on the Hong Kong Stock Exchange (HKSE). The sample chosen for investigation are 120firms from Hong Kong and all these firms are listed on the Hong Kong Stock Exchange. The sample companies were chosen randomly from the population so that the population has an equal chance of being selected into the sample. We derived data from companies' annual reports for the year 2012 from their official websites. The data includes dividend, earnings per share, firm debt, equity and the like.

We used data from companies' annual reports that were released on the website Hong Kong Exchange Clearing and Limited (HKEx). This secondary data is ideal for the study. Firstly, the annual reports for every listed company are all available on the website. Secondly, we can rely on the information that was released by the HKEX because it is a trustworthy database about the financial reports of Hong Kong listed companies. The following table shows the major source of the independent variables and dependent variable.

Table 2. Summary of Data Resources

\begin{tabular}{|l|l|l|}
\hline Category & Construct & Data source \\
\hline $\begin{array}{l}\text { Dependent } \\
\text { variable }\end{array}$ & Dividend yield & http://www.asstock.com \\
\hline $\begin{array}{l}\text { Independent } \\
\text { variables }\end{array}$ & $\begin{array}{l}\text { Profitability, Firm size, Firm Debt, } \\
\text { Ownership Structure, Firm Opportunities }\end{array}$ & $\begin{array}{l}\text { http://www.hkexnews.hk/listedco/listconews/a } \\
\text { dvancedsearch/search_active_main.aspx }\end{array}$ \\
\hline
\end{tabular}




\section{Results}

\subsection{Multiple Regression}

This study has made an effort to examine the association between dividend policy and five selected company performance attributes. These attributes are firm size, profitability, leverage, ownership structure, firm development and opportunity. Table 3 presents the summary statistics of all dependent variables used in the analysis. The statistics contains the mean, standard deviation, minimum, maximum, and median of variables (excluding dummy variables).

Table 3. Summary of Data Statistics

\begin{tabular}{|c|c|c|c|c|c|}
\hline Variables & Mean & Medium & Maximum & Minimum & Standard deviation \\
\hline EPS & 1.396 & 0.76 & 10.11 & -0.53 & 1.75 \\
\hline MCAP & 36.33 & 7 & 244.3 & 0.304 & 57.44 \\
\hline MBR & 1.51 & 0.95 & 13.19 & 0.14 & 1.97 \\
\hline DER & 1.53 & 0.64 & 13.19 & 0.02 & 2.698 \\
\hline
\end{tabular}

Table.4 shows the results of OLS under both estimation default and HAC coefficient covariance matrix. We use the Multiple OLS to estimate our Model 1, which includes all independent variables, and we use the t-test to examine the significance of our independent variables. As a robustness check, the insignificant variables will be eliminated from Model 1. We estimate Model 2 (Table.5) to check if the sign and magnitude of the coefficients would change. Meanwhile, the White heteroskedasticity test is conducted. Our result indicates that the null hypothesis of homoskedasticity is rejected. The Newey West (HAC) t-statistics are also reported .

In model 1, DYLD=1.041EPS+0.013MCAP+0.078MBR0.134DER+2.108Family+1.763State+1.512Inst $+\varepsilon i$

In Model 2, we leave out the insignificant variables in Model 1, and use the remaining variables to conduct the regression. The final model is,

DYLD=0.89EPS-0.011MCAP+2.4Family+1.82State+1.47Inst $+\varepsilon i$

There is no intercept in the equation to avoid the perfect multicollinearity. We can see that the DER is significant at 5\% level under estimation default but insignificant at 5\% level under HAC. Here we will use the results under the HAC because it is more precise in our case and it does better than estimation default in autocorrelation, or correlation, and heteroskedasticity in the error terms in the models.

According to Table.4 (Model 1), the independent variables EPS and our entire dummy variables including family, state and institution are significant under 0.05 significant level. Besides, the market capitalization is significant at 0.1 significant level. However, the MBR and DER are insignificant under 0.05 significant level. Therefore, we removed those insignificant independent variables and used the remaining variables in testing model 2 . The result of Model 2 (Table.5) shows that the EPS, and dummy variables family, state and institution are all positively and statistically significant under 5 percent level while the market 
capitalization is negatively and statistically significant under 10 percent level. The R-squared is the coefficient of determination and the results are 0.450911 in Model 1 and 0.427228 in Model 2, which is proper in our case.

Table. 4. Regression Result of Model 1

Dependent variable: dividend yield

Model 1

\begin{tabular}{|l|l|l|l|}
\hline & Coefficient & T-statistics & T-statistics (HAC) \\
\hline EPS & 1.041352 & $7.46354^{*}$ & $3.957672^{*}$ \\
\hline MCAP & -0.013022 & $-2.978164^{*}$ & $-1.946863^{* *}$ \\
\hline MBR & 0.07806 & 0.962312 & 0.949564 \\
\hline DER & -0.134188 & $-2.143205^{*}$ & -1.405203 \\
\hline FAMILY & 2.108317 & $5.420622^{*}$ & $3.12188^{*}$ \\
\hline STATE & 1.763444 & $6.167708^{*}$ & $5.627202^{*}$ \\
\hline INST & 1.512265 & $6.83749^{*}$ & $6.1804^{*}$ \\
\hline R-SQUARED & 0.450911 & & \\
\hline
\end{tabular}

Note: * significant at $5 \% ; * *$ significant at $10 \%$

Table.5 Regression Result of Model 2

Dependent variable: dividend yield

\begin{tabular}{|l|l|l|l|}
\hline & \multicolumn{2}{|l|}{ Model 2 } & \\
\hline & Coefficient & T-statistics & T-statistics (HAC) \\
\hline EPS & 0.8896 & $7.709955^{*}$ & $3.4687^{*}$ \\
\hline MCAP & -0.0112 & $-3.200737^{*}$ & $-1.7077^{* *}$ \\
\hline FAMILY & 2.4045 & $7.758525^{*}$ & $3.9605^{*}$ \\
\hline STATE & 1.8246 & $6.478454^{*}$ & $5.5557^{*}$ \\
\hline INST & 1.4739 & $7.046559^{*}$ & $6.7662^{*}$ \\
\hline$R$-SQUARED & 0.427228 & \\
\hline
\end{tabular}

Note: * significant at $5 \% ; * *$ significant at $10 \%$

Table 6. Summary of Final Results

\begin{tabular}{|l|l|l|l|}
\hline Hypotheses & Variables & Data Results & Assumed Relationship \\
\hline Profitability & EPS & Positive & Positive \\
\hline Firm size & MCAP & Negative & Positive \\
\hline Firm Debt & DER & None & Negative \\
\hline Ownership Structure & FAML & Positive & Negative \\
& STATE & Positive & Positive \\
& INST & Positive & Positive \\
\hline Firm Opportunities & MBR & None & Negative \\
\hline Dependent Variable & DYLD & & \\
\hline
\end{tabular}


Note: EPS: the after-tax earnings per share; MCAP: natural log of market capitalization; DER: debt-to-equity ratio; FAML: family dummy; STATE: state dummy; INST: institution dummy; MBR: market-to-book ratio; DYLD: dividend yield.

\subsection{Hypothesis Testing}

Contrary to Hypothesis 1, the coefficient of market capitalization (which represents the firm size) is negative both under Model 1 and Model 2.The t-statistics of the coefficients on MCAP for models 1and 2 are-1.946863and -1.7077, respectively, which are significant at 10 percent level. The negative correlation between dividend yield and size suggests that smaller firms are more able to pay dividends. This result may be attributed to the special feature of Hong Kong's capital market, in which a majority of the firms are relatively small in size when compared to the global companies. Definitions of the different market-cap categories may differ. Here, we use Standard \& Poor's standard:

- $\quad$ Large-cap company -- market value of $\$ 10$ billion or more.

- $\quad$ Midcap company -- market value between $\$ 3$ billion and $\$ 10$ billion.

- Small-cap company -- market value of $\$ 3$ billion or less.

Then, we found that in our selected firms, $69 \%$ of them were small-cap companies, while only $16 \%$ of the figures were large-cap companies.

This finding is not consistent with the pecking order theory and provides no support to agency-cost theories. In our study, larger companies prefer to retain their money to maintain internal financing but avoid external dividend paying, although it is easier for them to raising capital by issuing stocks. On the contrary, small firms, which are more risky, need to have a high payout ratio, in order to attract investors to buy their stock.

As shown in Table.4 and Table.5, the coefficient of earnings per share (EPS) is statistically significant and indicates a positive relationship with dividend yield, confirming Hypothesis 2.The estimates of EPS are all positive and significant at the 5 percent level under Model 1 and Model 2. It indicates that theories about profitability also can be applied to Hong Kong firms and it is a critical determinant of corporate dividend payout policy. It is worth mentioning that the profitability variable does not seem to have large economic importance. We can conclude that the firms with high profitability are tend to pay more or lager dividend because they can afford their internal financing. Besides, they even need to earn reputation and competitiveness in the financial market by paying competitive dividends.

The financial leverage is an index of a company to get an idea of the company's methods of financing or to measure its ability to meet financial obligations. It is represented by the debt-to-equity ratio (DER) in our study, and we predicted it will be negatively related with the dividend yield (Hypothesis 3). However, the results show that it is negatively related but the coefficient of DER is insignificant at 5 percent level under Model 1, and is removed from Model 2. The finding suggests there is no relationship between debt-equity ratio and dividend payout. The reasons why it is insignificant are:

- $\quad$ Some firms who have high leverage are still willing to increase debt to finance 
increasing dividends in order to send a strong positive signal to institutional owners or investors to enhance reputation and maintain access to capital. (Myers \&Frank, 2004)

- $\quad$ Fama and French (2000) proposed an idea that debt is the residual.

The ownership structure is represented by three dummies, which are family, state, and institution in Hypothesis 4. According to the results, all of these dummy variables are positively and statistically significant at 5 percent level under both Model 1 and Model 2. Table. 4 and Table. 5 depict the t-statistics of the coefficients on these three variables are 3.12188, 5.6272 and 6.1804 respectively under Model 1, while 3.9605, 5.5557 and 6.7662 in Model 2. They are all highly related with dividend yield and institution-owned companies have highest correlation. In other words, ceteris paribus, if the biggest stockholder is an institution, this company is likely to pay more dividends compared others. Our result (Table.5) indicates that family owned firms, on average, pay 0.6 per cent more than State-owned firm. The difference relative to institution-owned firms is almost one per cent. The positive significant relationship between dividend yield and STATE and INST are consistent with the literature review we mentioned, while family-owned firms show positive relationship with dividend instead of negative relationship surprisingly. Most researches (for example, Lam \& Lee, 2012; Gugler, 2003; He \& Li, 2011) show that family ownership companies tend to decrease dividend since they have complex agency cost problem (unskilled family members, lack of diversification, and poor transparency for other shareholders). This finding in our study indicates that family mechanism in Hong Kong is sufficient and effective. Base on our data, the proportion of institutional ownership firms (57\%) is nearly three times the figure for family or state-owned firms (23\%). Considering that our selected firms are dividend-paying companies, we suggest that most of dividend paying companies is institution-owned.

Hypothesis 5 suggests that the market-to-book ratio, which stands for the firm's growth opportunities, is negatively related to our dependent variable as those firms tend to retain their income to finance their investments. Surprisingly, it is shown that the coefficient of MBR is not significant at 5 percent level in regression results. These findings indicate that the market-to-book value ratio is not related to dividend yield. The result is consistent with the prior research of Husam-Aldin (2007), who found that there is no significant relationship between MBR and dividend payout. However, the hypothesized relationship between dividends and firms' development and opportunities could not be rejected since the other proxy variable such as firm age is not examined. Some researches including the one of Husam-Aldin have provided evidence about it. 


\section{Ml Macrothink \\ Business and Economic Research \\ ISSN 2162-4860 \\ 2014, Vol. 4, No. 2}

\section{Limitations and Future Research}

One limitation of this study is that we only focused on the Hong Kong market, so the conclusion we make is only suitable for Hong Kong companies. As the business cycles and other macroeconomic factors differ between different countries, these disturbances may lead to unexpected influence on the final results. In this model, we are trying to minimize these effects.

At the same time, we should consider an independent variable, ownership structure, which is divided into state, family and institution owned. For thousands of listed companies in HK, it is quite a rough classification. Actually, there are also foreign or multi-owned firms, but numbers of these kinds of firms are few. We have tried to find factors that might be contributing to the dividend decision in Hong Kong but as it varies for each country, the list cannot be exhaustive.

As we are using specific statistical methods to verify our model, the basic limitations of statistical methods used will apply to our model also. Researchers also use other models such as Tobit Model, which may lead to different results.

For the constraints of budget and time, when analyzing data we selected the cross-sectional study, not a longitudinal study. Because more data will cause more complex results and variations, only the data in 2012 are being used in our analysis. Future researchers can use time series method to make a more precise data analysis. At last, there is limited control of corporate and business risks ${ }^{1}$.

\footnotetext{
${ }^{1}$ For application of Chinese stock markets and corporation, see Fung and Wan (2013) and Yang (2003).
} 


\section{Conclusion}

Based on our research, investors can consider the significant determinants of companies' dividend yield when deciding on investment in Hong Kong stocks. According to the clientele effect hypothesis, different types of investors prefer different level of payout. Therefore, if investors' interest is the high dividend from their investment, they can expect high dividend yield based on high EPS of the company, or avoid those have large market capitalization. And intuitional-owned firms, based on our study, are more willing to pay dividends than others. If investors' interest is the low dividend payout, they can pay attention to the firms who have high investment opportunities because these kinds of firms tend to retain their dividends for reinvestment.

For the company who want to keep access to the capital market and maintain the reputation and attractions for investors, they need to keep the dividends stable rather than changing a lot. As most of relative small firms are thought to be risky, it is better for them to distribute more dividends to attract majority investors. Keeping profitable to convey positive signaling is also important. For the larger companies, show high growth opportunities if they do not willing to pay high dividends and therefore they can still attract investors.

The thing worth mention is that the study result especially fits Hong Kong situation and their similar markets.

\section{References}

Adil, C. M., Zafar, N., \& Yaseen, N. (2011). Empirical analysis of determinants of dividend payout: Profitability and liquidity.Interdisciplinary Journal of Contemporary Research in Business, 3(1), 289-300.

Allen, F., \& R. Michaely (2003), Payout Policy, in G. M. Constantinides, M. Harris and R. M. Stulz (eds), Handbook of the Economics of Finance, Chapter 7, 1st edn. Vol.1, Amsterdam: Elsevier, pp. 337-429.

Al-ShubiriI, F., Al Taleb, G., \& Al- Zoued, A. (2012). The Relationship between Ownership Structure and Dividend Policy: An Empirical Investigation. Review Of International Comparative Management / Revista De Management Comparat International, 13(4), 644-657.

Ambarish R., John, K., \& Willams, J (1987). EfficientSignalling with Dividends and Investments. Journal Of Finance, 321-343. http://dx.doi.org/10.1111/j.1540-6261.1987.tb02570.x

Amidu, M. (2007). How Does Dividend Policy Affect Performance of the Firm of Ghan Stock Exchange?Investment Management \& Financial Innovations, 4(2), 103-112,148.

Azeem, M., MS, Akbar, Z., M. S., \& Usman, A. (2011). Investigating compliance of dividend policy with firm size: A case of karachi stock exchange listed companies. Interdisciplinary Journal of Contemporary Research in Business, 2(11), 263-279.

Balachandran, B., Mahamuni, M., \& Dempsey, M. J. (2010). Special dividend announcements: Signaling or free cash flow hypothesis ' evidence from UK firms. Rochester: Social Science 
Research Network.

Banerjee, S., Gatchev, V., \& Spindt, P. (2007). Stock market liquidity and firm dividend policy. Journal ofFinancial and Quantitative Analysis, 42(2), 369-384. http://dx.doi.org/10.1017/S0022109000003318

Bansal, D. (2004). Dividend policy : Its impact on firm value. Finance India,18(1), 264-265.

Ben Naceur, S., Goaied, M., \& Belanes, A. (2006). On the Determinants and Dynamics of Dividend Policy. International Review of Finance, 6(1/2), 1-23. http://dx.doi.org/10.1111/j.1468-2443.2007.00057.x

Bhattacharya, S. (1979).Imperfect information, dividend policy, and "the bird in the hand" fallacy. Bell Journal of Economics, 10(1), 259-270. http://dx.doi.org/10.2307/3003330

Black, F. (1976), 'The Dividend Puzzle', Journal of Portfolio Management, 2, 5-8. http://dx.doi.org/10.3905/jpm.1976.408558

Borokhovich, K. A., Brunarski, K. R., Harman, Y., \&Kehr, J. B. (2005).Dividends, Corporate Monitors and Agency Costs. Financial Review, 40(1), 37-65. http://dx.doi.org/10.1111/j.0732-8516.2005.00092.x

Brealey, R., \& S. Myers (2005), Principles of Corporate Finance, $8^{\text {th }}$ edn. London: McGraw-Hill

Dale-Johnson, D. (1983). Clientele effects on the demand for housing price appreciation. AREUEA Journal, 11(3), 382. http://dx.doi.org/10.1111/1540-6229.00297

Erkaningrum, I. F. (2013). Interactions Among Insider Ownership, Dividend Policy, Debt Policy, Investment Decision, And Busniess Risk. Journal of Indonesian Economy and Business : JIEB., 28(1), 132-148,159.

Faccio, M., L. H. P. Lang, \& L. Young, (2001). Dividends and Expropriation, American Economic Review 91, 54-78. http://dx.doi.org/10.1257/aer.91.1.54

Fama, E. F., \& French, K. R. (2002). Testing trade-off and pecking order predictions about dividends and debt. The Review of Financial Studies, 15(1), 1-33. http://dx.doi.org/10.1093/rfs/15.1.1

Fung, K. W. T., \& Wan. W, (2013). The Impact of Merger and Acquisition on Value at Risk (VaR): A Case Study of China Eastern Airline. International Research Journal of Finance and Economics. 110, 121-127

Fung, K.W. T., Lau, C. K. M., \& Chan, K. H., (2014). The Conditional CAPM, Cross-Section Returns and Stochastic Volatility. Economic Modelling. 38, 316-327. http://dx.doi.org/10.1016/j.econmod.2014.01.009

Green, P., Pogue, M., \& Watson, I. (1993). Dividend policy and its relationship to investment and financing policies: Empirical evidence using irish data. IBAR, 14(2), 69.

Griffin, C. H. (2010). Liquidity and dividend policy: International evidence. International 
Business Research, 3(3), 3-9. http://dx.doi.org/10.5539/ibr.v3n3p3

He, T., Li, W., \& Tang, G. (2012). Dividends Behavior in State- Versus Family-Controlled Firms: Evidence from Hong Kong. Journal Of Business Ethics, 110(1), 97-112. http://dx.doi.org/10.1007/s10551-011-1150-0

Hong Kong Trade Development Council (2012). Economic and Trade Information on Hong Kong. Retrieved October 13, 2012, from http://www.hktdc.com/info/mi/etihk/en/

Hong kong: Tax regulations. (2010). New York: The Economist Intelligence Unit.

Husam-Aldin, N. A. (2007). Determinants of corporate dividend policy in jordan: An application of the tobit model. Journal of Economic and Administrative Sciences, 23(2), 44-70. http://dx.doi.org/10.1108/10264116200700007

Jagannathan, R., \& Wang Z., (1996). The Conditional CAPM and the Cross-Section of Expected Returns. The Journal of Finance. 51, 3-53. http://dx.doi.org/10.1111/j.1540-6261.1996.tb05201.x

Jing-Ming Kuo, Dennis Philip, \& Qingjing Zhang (2013). What drives the disappearing dividends phenomenon?. Journal of Banking \& Finance, 37(9), September 2013, Pages 3499-3514, ISSN 0378-4266.

Kapoor, S., Mishra, A., \& Anil, K. (2010).Dividend Policy Deerminants Of India Service Sector: A Factorial Analysis. Paradigm, 14(1), 24-41.

Kumar, J. (2012). Ownership structure and dividend payout policy in india. Rochester: Social Science Research Network. http://dx.doi.org/10.2139/ssrn.474103

Li, K., \& Zhao, X. (2008).Asymmetric information and dividend policy. Financial Management, 37(4), 673-694. http://dx.doi.org/10.1111/j.1755-053X.2008.00030.x

Marr, M. W., \& Trimble, J. L. (1993).Eurobond financing bargains and the clientele hypothesis. Journal of Business Research, 27(3), 201. http://dx.doi.org/10.1016/0148-2963(93)90026-L

Miller, M. H., \& Modigliani, F. (1961).Dividend Policy, Growth, And The Valuation Of Shares.The.The Journal of Business (Pre-1986), 34(4), 411. (Oct., 1961) , pp. 411-433. http://dx.doi.org/10.1086/294442

Myers, M., \& B. Frank. (2004). The Determinants of Corporate Dividend Policy, Academy of Accounting and Financial Studies Journal, Vol. 8, No. 3, 17-28.

Savov, S. (2006). Dividend changes, signaling, and stock price performance. Rochester: Social Science Research Network. http://dx.doi.org/10.2139/ssrn.933082

Thanatawee, Y. (2013). Ownership structure and dividend policy: Evidence from thailand. International Journal of Economics and Finance, 5(1), 121-132. Retrieved from http://search.proquest.com/docview/1285157332? accountid=38789

Tin-yan, L., \& Shu-kam, L. (2012). Family ownership, board committees and firm performance: Evidence from hongkong.Corporate Governance, 12(3), 353-366. 
http://dx.doi.org/10.1108/14720701211234609

Warrad, L., Abed, S., Khriasat, O., \& Al-Sheikh, I. (2012). The effect of ownership structure on dividend payout policy: Evidence from jordanian context. International Journal of Economics and Finance, 4(2), 187-195. http://dx.doi.org/10.5539/ijef.v4n2p187

Waweru, K. M., Pokhariyal, G. P., \&Mwaura, M. F. (2012). The Signaling Hypothesis: Evidence From The Nairobi Securitirs Exchange Journal of Business Studies Quarterly, 3(4), 105-118.

\section{Copyright Disclaimer}

Copyright for this article is retained by the author(s), with first publication rights granted to the journal.

This is an open-access article distributed under the terms and conditions of the Creative Commons Attribution license (http://creativecommons.org/licenses/by/3.0/). 